\title{
Faktor-Faktor Penyebab Terpilihnya Anggota Legislatif dari Partai Gerindra di Kabupaten Aceh Tamiang Pada Tahun 2019
}

\section{Factors Causing the Election of Legislative Members from the Gerindra Party in Aceh Tamiang District in 2019}

\author{
M. Luthfi Hidayat, R. Hamdani Harahap* \& Amir Purba \\ Fakultas Ilmu Sosial dan Ilmu Politik, \\ Universitas Sumatera Utara, Indonesia
}

Diterima: 05 Juni 2021; Direview: 05 Juni 2021; Disetujui: 29 November 2021

\begin{abstract}
Abstrak
Kabupaten Aceh Tamiang merupakan salah satu Kabupaten melalui pemekaran pada tahun 2002 di Provinsi Aceh, Pada Pemilihan Legislatif tahun 2019 Partai Gerindra Kabupaten Aceh Tamiang berhasil mengalahkan Partai yang selalu menjadi partai pemenang di periode sebelum-sebelumnya yaitu Partai Aceh, partai yang berideologikan religius atau islam konservatif. Perolehan suara mayoritas yang diraih oleh Partai Gerakan Indonesia Raya dengan mendapatkan 6 kursi atau 20\% dari total keseluruhan kursi DPRK Aceh Tamiang. Penelitian ini dilakukan dengan wawancara mendalam terhadap 5 (lima) orang informan dan Diskusi Kelompok Terfokus (DKT) terhadap 5 (lima) orang, para informan menjawab tentang faktor-faktor apa saja yang menyebabkan terpilihnya anggota legislatif di Kabupaten Aceh Tamiang Tahun 2020. Banyak kalangan beranggapan bahwa uang dan kepopuleran modal utama dalam memenangkan kontestasi Pileg. Tetapi dalam konteks Pileg Aceh Tamiang tahun 2019 silam tidak sepenuhnya demikian, banyak faktor lain yang menyebabkan terpilihnya anggota-anggota legislatif dari Partai Gerindra. Karena banyak caleg yang memiliki modal dana lebih banyak tapi tidak terpilih, keterpilihan anggotaanggota legislatif dipengaruhi oleh rekam jejak yang baik, kinerja tim sukses yang sangat massif, dan dukungan tokoh agama dan tokoh masyarakat.

Keywords: Faktor Penyebab; Anggota Legislatif; Aceh Tamiang.
\end{abstract}

\begin{abstract}
Abstrack
Aceh Tamiang Regency is one of the regencies through the division in 2002 in Aceh Province. In the 2019 Legislative Election, the Gerindra Party of Aceh Tamiang Regency succeeded in defeating the Party that has always been the winning party in the previous period, namely the Aceh Party, a party with religious ideology or conservative Islam . The majority vote was won by the Great Indonesia Movement Party by getting 6 seats or 20\% of the total seats in the Aceh Tamiang DPRK. This research was conducted with in-depth interviews with 5 (five) informants and Focus Group Discussions (DKT) with 5 (five) people, the informants answered about what factors led to the election of legislative members in Aceh Tamiang Regency in 2020. Many people assumes that money and the popularity of the main capital in winning the Pileg contestation. However, in the context of the 2019 Aceh Tamiang Pilleg, this was not entirely the case, many other factors led to the election of legislative members from the Gerindra Party. Because many candidates who have more financial capital but are not elected, the electability of legislative members is influenced by their good track record, massive performance of the success team, and the support of religious and community leaders.
\end{abstract}

Keywords: Causative factor; Legislative Members; Aceh Tamiang

How to Cite: Hidayat, M.L Harahap, R.H. \& Purba, A. (2022). Faktor-Faktor Yang Menyebabkan Terpilihnya Anggota Legislatif Dari Partai Gerindra Di Kabupaten Aceh Tamiang Pada Tahun 2019. PERSPEKTIF 11 (1) : 88-97

\begin{tabular}{lr}
\hline *Corresponding author: & ISSN 2085-0328 (Print) \\
E-mail: $\underline{\text { r.hamdani@usu.ac.id }}$ & ISSN 2541-5913 (online)
\end{tabular}




\section{PENDAHULUAN}

Pembangunan adalah suatu proses untuk memajukan taraf hidup masyarakat dan warganya. Pembangunan bukan hanya sematamata dalam bentuk fisik. Proses peningkatan demokrasi (demokratisasi) juga merupakan suatu proses pembangunan. Dalam proses demokratisasi tersebut, diharapkan meningkatnya kesadaran politik rakyat dalam memperjuangkan hak-haknya sebagai warga negara.

Demokrasi adalah suatu sistem pemerintahan dimana kedaulatan tertinggi berada di tangan rakyat. Adapun, secara etimologis demokrasi berasal dari bahasa Yunani, yaitu "demos" yang berarti rakyat dan "kratos atau kratein" yang berarti kekuasaan atau berkuasa. Demokrasi dapat diartikan rakyat berkuasa atau "government or rule by the people" (pemerintahan oleh rakyat). Dengan kata lain, demokrasi berarti pemerintahan yang dijalankan oleh rakyat, baik secara langsung maupun tidak langsung, umum, bebas, rahasia, jujur, dan adil (Luber dan Jurdil). Menurut Abraham Lincoln, "Demokrasi adalah suatu pemerintahan yang berasal dari rakyat, oleh rakyat dan untuk rakyat" (Iver, 1984).

Dapat disimpulkan bahwa pemegang kekuasaan yang tertinggi dalam suatu sistem demokrasi yaitu ada di kuasa rakyat dan rakyat memiliki hak, kesempatan dan suara yang sama untuk mengontrol dan mengatur kebijakan pemerintah melalui keputusan yang terbanyak, salah satu wujud dari demokrasi adalah Pemilihan Umum (Pemilu). Pemilu adalah sarana pelaksanaan kedaulatan rakyat yang dilaksanakan secara demokratis dalam Negara Kesatuan Republik Indonesia berdasarkan Pancasila dan Undang-undang Dasar Negara Republik Indonesia tahun 1945.

Undang-undang Republik Indonesia Nomor 07 Tahun 2017, pasal 1 ayat 1 yang berbunyi Pemilihan Umum yang selanjutnya disebut. Pemilu adalah sarana kedaulatan rakyat untuk memilih anggota Dewan Perwakilan Rakyat, anggota Dewan Perwakilan Daerah, Presiden dan Wakil Presiden, dan untuk memilih anggota Dewan Perwakilan Rakyat Daerah yang dilaksanakan secara langsung, umum, bebas, rahasia, jujur, dan adil dalam Negara Kesatuan Republik Indonesia. Hal ini berdasarkan Pancasila dan UndangUndang Dasar Negara Republik Indonesia Tahun 1945 (Undang-Undang Republik
Indonesia Nomor 7 Tahun 2017 Tentang Pemilihan Umum, n.d.).

Sejauh ini prinsip dan nilai demokratis di atas belum menampakan perkembangan maksimal. Padahal prinsip tersebut merupakan unsur mendasar bagi proses perubahan kehidupan politik lokal yang lebih baik. Ketimpangan tersebut tidak lepas dari tradisi dan budaya politik yang diartikulasikan oleh elit struktural, khususnya anggota legislatif daerah.

Di satu sisi era demokratisasi dewasa ini sangat membanggakan hati. Namun, disisi lain masyarakat banyak terjebak kepada ketidaktahuan esensi demokrasi itu sendiri. Bagi masyarakat, sekarang demokrasi dijadikan sebuah tujuan. Padahal menurut pikiran umum demokrasi hanya sekedar alat untuk mencapai tujuan. Pemahaman masyarakat yang demikian itulah yang menyebabkan pemilu dijadikan obyek untuk mengeruk keuntungan materil bagi masyarakat. Kecenderungan ini sekarang sudah menjadi budaya demokrasi di tengahtengah masyarakat kita. Bergesernya nilai-nilai demokrasi di tengah masyarakat karena pelaksanaan pilkada banyak diwarnai praktekpraktek perusakan sendi-sendi demokrasi misalnya jurus politik uang.

Partisipasi merupakan salah satu aspek penting dalam kehidupan berdemokrasi. Asumsi yang mendasari demokrasi dan partisipasi adalah orang yang paling tahu tentang apa yang baik bagi dirinya adalah orang itu sendiri. Karena keputusan politik yang dibuat dan dilaksanakan oleh pemerintah menyangkut dan memengaruhi kehidupan warga masyarakat, maka warga masyarakat berhak ikut serta menentukan isi keputusan politik. Oleh karena itu, yang dimaksud dengan partisipasi politik ialah keikutsertaan warga negara biasa dalam menentukan segala keputusan yang menyangkut atau memengaruhi hidupnya.

Sebuah kegiatan pemasaran politik sedapat mungkin diawali dengan kegiatan pembentukan tim kerja yang biasa disebut "Tim Sukses". Tim sukses direkrut dari tenagatenaga potensial sesuai tugas dan fungsinya. Sebuah tim suksess biasanya terdiri dari : Penasihat, Tim Ahli, Tim Riset, Tim Pengumpul Dana, Tim Kampanye, Tim Penggalangan Massa, Tim Pengamat, Tim Pengaman dan Tim Pengumpul Suara. 
Kampanye adalah sebuah tindakan dan usaha yang bertujuan mendapatkan pencapaian dukungan, usaha kampanye dilakukan guna mempengaruhi masayarakat untuk memberikan dukungannya terhadap partai politik dan calon legislatif. Ada beberapa langkah yang bisa ditempuh dalam perencanaan komunikasi untuk kampanye, yakni Analisis khalayak dan kebutuhannya, Penetapan sasaran atau tujuan komunikasi, Rancangan strategi yang mencakup: komunikator, saluran atau media, pesan dan penerima, Penetapan tujuan pengelolaan serta Implementasi perencanaan yang mencakup besarnya dana, sumber dana dan waktu (Fatkhurohman, 2010).

Partai politik adalah suatu kelompok yang terorganisasi yang anggota-anggotanya mempunyai orientasi, nila-nilai, dan cita-cita yang sama (Budiarjo, 2008). Pengertian partai politik menurut Undang-Undang Republik Indonesia No. 2 tahun 2011, Pasal 1 ayat 1 dinyatakan bahwa Partai Politik adalah organisasi yang bersifat nasional dan dibentuk oleh sekelompok warga negara Indonesia secara sukarela atas dasar kesamaan kehendak dan cita-cita untuk memperjuangkan dan membela kepentingan politik anggota, masyarakat, bangsa dan negara, serta memelihara keutuhan Negara Kesatuan Republik Indonesia berdasarkan Pancasila dan Undang-Undang Dasar Negara Republik Indonesia Tahun 1945 (Undang-Undang Republik Indonesia Nomor 2 Tahun 2011 Tentang Partai Politik, n.d.). Tujuan kelompok ini adalah untuk memperoleh kekuasaan politik dan merebut kedudukan politik untuk melaksanakan programnya. Adapun fungsi partai politik di Negara demokrasi sebagai sarana komunikasi politik, sosialisasi politik, rekrutmen politik, dan pengatur konflik (Budiarjo, 2008).

Dalam sejarah kontestasi Pemilihan Legislatif di Aceh, sejak Partai Gerakan Indonesia Raya atau Partai Gerindra yang berdiri dan diketuai oleh Prabowo Subianto pada tanggal 6 Februari 2008. Partai ini berjati dirikan Kebangsaan, Kerakyatan, Religius, dan Keadilan Sosial dan berazaskan Pancasila dan Undang-Undang Dasar 1945. Pada kenyataannya, dalam pelaksanaan pemilu di Aceh kader dari Partai Gerindra Aceh tidak pernah memenangkan kursi di DPR RI. Bahkan di tingkat lokal Aceh, Gerindra sama sekali belum mendapatkan tempat dihati masyarakat Aceh.

Namun, kondisi dan dinamika politik berubah paska afiliasi politik antara Partai Aceh dan Partai Gerindra Aceh. Partai Gerindra berhasil mendapatkan kursi untuk DPR RI di dua dapil Aceh yang tersedia dan beberapa kursi di DPR dan DPRK seluruh Aceh. Keuntungan itulah yang yang didapatkan Partai Gerindra dari hasil afiliasi dengan Partai Aceh. Munculnya nama Ketua Umum Partai Aceh, Muzakir Manaf sebagai Ketua Dewan Pembina Partai Gerindra Aceh pada tahun 2014 mempertegas bentuk koalisi antara Partai Aceh dan Partai Gerindra pada Pemilu 2014 hingga saat ini (Fauzi, 2018).

Partai Gerindra mulai mendapat $u$ kemenangan pemilu saat di bawah kepemimpinan Suprianto, ST. Partai Gerindra Kabupaten Aceh Tamiang berhasil mengalahkan Partai yang selalu menjadi partai pemenang di periode sebelum-sebelumnya yaitu Partai Aceh. Partai yang berideologikan religius atau islam konservatif dengan memperoleh hanya memperoleh 4 kursi di periode 2019 - 2024 atau hanya 13\% dari keseluruhan kursi DPRK. Pereolehan ini bisa dikatakan menurun dari periode sebelumnya yaitu pada periode 2014 - 2019 dengan memperoleh 6 kursi.

Secara keseluruhan, Dewan Perwakilan Rakyat Kabupaten Aceh Tamiang memiliki 30 orang anggota yang tersebar di 10 partai politik. Pada pelaksaanaan pemilu 2019 dengan perolehan suara mayoritas yang diraih oleh Partai Gerakan Indonesia Raya dengan mendapatkan 6 kursi atau 20\% dari total keseluruhan kursi DPRK Aceh Tamiang.

Dewan Perwakilan Aceh Tamiang berkomposisikan oleh tiga partai pemenang yang menduduki kursi Pimpinan yaitu Partai Gerindra mendapatkan Kursi Ketua DPRK, Partai Aceh mendapatkan Kursi Wakil Ketua I, dan Partai Demokrat yang memperoleh kursi Ketua II, dan disusul dengan partai-partai lain seperti Partai Keadilan Sosial dengan perolehan 3 kursi dan urutan terbawah adalah Partai Demokrasi Indonesia Perjuangan dengan ideologi Nasionalismenya dan Partai PBB yang berideologi Islamisme dengan perolehan masing-masing 1 kursi. 


\section{METODE PENELITIAN}

Penelitian ini dilakukan dengan menggunakan metode deskriptif karena bermaksud menggambarkan fenomena sosial tertentu, dengan pendekatan kualitatif. Jenis penelitian ini memberikan uraian yang lebih lengkap tentang suatu keadaan untuk memberikan gambaran yang lebih lengkap tentang pelaksanaan Pileg di Kabupaten Aceh Tamiang. Pendekatan kualitatif lebih menekankan pada pengamatan fenomena dan lebih meneliti ke subtansi makna dari fenomena tersebut. Analisis dan ketajaman penelitian sangat terpengaruh pada kekuatan kata dan kalimat yang digunakan. Perhatian penelitian lebih tertuju pada elemen manusia, objek, dan institusi, serta hubungan atau interaksi di antara elemen-elemen tersebut, dalam upaya memahami suatu peristiwa, perilaku, atau fenomena (Basri, 2014).

\section{HASIL DAN PEMBAHASAN \\ Pemilihan Legislatif Kabupaten Aceh Tamiang Tahun 2019}

Aceh merupakan salah satu wilayah di Indonesia yang memiliki peraturan khusus atau asimetrik terutama dalam penyelenggaraan Pemilu. Ada beberapa hal yang dapat menyebabkan terjadinya aturan tidak seimbang atau asimetrik. Pertama, adanya konsensus historis yang dituangkan dalam konstitusi sehingga menciptakan daerahdaerah khusus dan istimewa, termasuk hak khusus bagi elit tertentu dalam aspek politik. Konstitusi Indonesia dalam UUD 1945, mengakui dan menghormati satuan-satuan pemerintahan daerah yang bersifat khusus atau istimewa. Satuan-satuan khusus atau istimewa tersebut diakui dan dihormati berdasarkan pertimbangan tertentu seperti sejarah, politik, administrasi, ekonomi dan sosial budaya. Faktor-faktor semacam itu seringkali tidak berdiri sendiri, namun terkait satu sama lain sehingga membentuk keunikan dan pertimbangan dalam penentuan daerah khusus.

Kabupaten Aceh Tamiang adalah salah satu kabupaten yang terdapat di Provinsi Aceh, Indonesia. Kabupaten ini adalah hasil pemekaran dari Kabupaten Aceh Timur yang diresmikan pada 2 Juli 2002 berdasarkan UU No.4 Tahun 2002. Kabupaten yang mempunyai semboyan "Kaseh pape setie mati" ini terletak dekat dengan perbatasan Sumatera Utara.
Kabupaten ini berada di jalur timur Sumatera yang strategis dan hanya berjarak lebih kurang $250 \mathrm{~km}$ dari Kota Medan sehingga akses serta harga barang di kawasan ini relatif lebih murah daripada daerah Aceh lainnya.

Perjalanan demokrasi memang perlu ditanamkan di dalam diri masyarakat, karena hampir semua masyarakat dan elitnya sepakat bahwa pola demokrasi harus dipertahankan dalam menjalankan perpolitikan di Indonesia, tidak terkecuali Aceh. Kekuatan ini harus terus dikembangkan, karena pola Autoritarian yang dikembangkan dimasa Orde baru. Akibatnya hampir semua masyarakat menklaim bahwa pola perpolitikan dimasa tersebut dinyatakan gagal dalam menjalankan pola ruang publik dalam berkreasi. Untuk itu perlu semangat positif yang diarahkan dalam menjawab tantangan pasca reformasi. Meskipun Aceh memiliki historis yang panjang terhadap konflik, tetapi tidak membuat semangat demokrasi harus pudar tetapi semangat tersebut terus dikembangkan untuk menuju yang lebih baik.

Pemilihan umum yang dilaksanakan di Aceh selama ini lebih dikenal dengan electoral threshold (ET). Sistem pada kebiasaan digunakan sebagai batas perolehan suara partai-partai politik untuk mendapatkan suara yang lebih banyak dan maksimal sebagaimana yang diharapkan dalam Pemilu. Sementara mekanisme yang telah diterapkan ini dalam UU No. 2 Tahun. 2008 tentang Partai Politik.

Tentunya mekanisme yang demikian akan berimplikasi positif terhadap kemampuan anggota partai parlemen yang telah dipilih. Hal ini bertujuan untuk menjalankan fungsinya sebagai wakil rakyat yang memadai dan maksimal. Implikasi dari penerapan sistem ET terhadap pemilu 2014 sangat berpengaruh pada suara yang didapati oleh setiap parpol maupun parlok untuk dapat menduduki parlemen. Menurut Urbaningrum, ET sendiri memiliki dua jenis yang berbeda. Pertama, threshold untuk bias ikut pemilu Berikutnya (electoral threshold) dan kedua, threshold untuk bisa masuk di parlemen (parlementary threshold). Sedangkan secara lebih spesifik Erawan mendefenisikan, parlementary threshold adalah hak partai politik di Parlemen yang diukur dari banyaknya jumlah kursi yang diperoleh.

Aceh merupakan salah satu wilayah di Indonesia yang memiliki peraturan khusus atau 
asimetrik terutama dalam penyelenggaraan Pemilu. Ada beberapa hal yang dapat menyebabkan terjadinya aturan tidak seimbang atau asimetrik. Pertama, adanya konsensus historis yang dituangkan dalam konstitusi sehingga menciptakan daerahdaerah khusus dan istimewa, termasuk hak khusus bagi elit tertentu dalam aspek politik.

Banyak hal yang membedakan antara pelaksanaan Pemilu dan Pilkada Aceh dengan Pemilu dan Pilkada daerah lain pada umumnya di Indonesia. Terjadinya perbedaan tersebut sebagai akibat dari lahirnya Undang-Undang Nomor 11 Tahun 2006 tentang Pemerintahan Aceh ini. Salah satunya yang paling mencolok dan dominan yaitu terkait dengan persoalan rekrutmen Penyelenggara Pemilu. Pada Pasal 23 Ayat (1) huruf l dan pasal 24 Ayat (1) huruf i yang menyatakan bahwa penyelenggara pemilu di Aceh di usulkan oleh anggota legislatif. Pasal lainnya yang menyangkut dengan persoalan rekrutmen penyelenggara pemilu terdapat pada pasal 56 Ayat (4) dan (5) yang menyatakan bahwa, "Anggota KIP Aceh diusulkan oleh Dewan Perwakilan Rakyat Aceh (DPRA) dan ditetapkan oleh KPU dan diresmikan oleh Gubernur. Anggota KIP Kabupaten/Kota diusulkan oleh Dewan Perwakilan Daerah Kabupaten/Kota (DPRK) ditetapkan oleh KPU dan diresmikan oleh bupati/walikota." Ditambah lagi pasal 56 Ayat (6) yang menyatakan, "Dalam melaksanakan ketentuan sebagaimana dimaksud pada ayat (4) dan (5), DPRA/DPRK membentuk tim independen yang bersifat ad hoc untuk melakukan penjaringan dan penyaringan calon anggota KIP."

Situasi yang konfliktual masih mewarnai pesta demokrasi di Provinsi Aceh. Sebagai daerah pasca konflik, potensi kekerasan politik masih terus muncul terutama menjelang diadakannya pemilihan umum (Pemilu) baik pemilu legislatif maupun pilkada. Berbagai laporan pemantauan pemilu dari tahun ketahun menunjukkan bahwa Provinsi Aceh selalu mengalami berbagai kasus pelanggaran pemilu. Kasus-kasus ini pada akhirnya berimplikasi terhadap konflik pemilu dan mengganggu stabilitas keamanan. Pada dasarnya, baik pemilu legislatif maupun pilkada menyimpan potensi konflik yang hampir sama. Keduanya saling berhubungan dalam konteks relasi elit-elit politik yang bertarung.
Pasca musibah gempa Tsunami 26 Desember 2004, kedatangan para relawan kemanusiaan dari berbagai penjuru dunia telah memulihkan kembali infrastruktur dan supra struktur kehidupan masyarakat di beberapa kabupaten dan kota di Aceh. Selanjutnya, beberapa bulan kemudian tanggal 15 Agustus 2015, ditanda-tanganinya MOU Helsinki anatara pihak pemerintah Republik Indonesia dan Gerakan Aceh Merdeka, yang menandai berakhirnya konflik yang berkepanjangan di Aceh. Suasana kondusif yang terus berlangsung, menempatkan Aceh untuk kembali menata dan menjalankan aktifitas pembangunan diberbagai bidang kehidupan.

Undang-Undang Pemerintahan Aceh No 11 tahun 2006, sebagai implementasi butirbutir MOU Helsinki, memberikan paradigma baru dalam kehidupan pembangunan politik di Aceh. Yaitu adanya penyerapan demokrasi lokal untuk pertama kali (pasca Reformasi 1998), dilaksanakan dalam pemilihan umum legislatif. Pelaksanaan pemilu legislatif 2009 di Aceh, selain dikuti oleh Partai Nasional (Parnas), juga Partai Lokal (Parlok). Peraturan Pemerintah Republik Indonesia Nomor 20 Tahun 2007 memberikan hak kepada Aceh untuk mendirikan partai lokal tersendiri, namun Undang-Undang tersebut tidak terlepas bagi partai lokal untuk berkompetisi dengan partai nasional. Awal Pemilu legislatif pada tahun 2009 melahirkan catatan sejarah yang sangat besar bagi aceh dikarnakan kemenangan partai lokal yang sangat signifikan.

Pemilu legislatif 2014 di Aceh selain diikuti 12 partai nasional (parnas) juga melibatkan 3 partai lokal (parlok) yaitu Partai Aceh (PA), Partai Nasional Aceh (PNA), dan Partai Damai Aceh (PDA). Jumlah ini lebih sedikit dibanding pada saat berlangsungnya Pemilu Legislatif 2009 yang melibatkan 6 partai lokal yaitu (Partai Aceh/PA, Partai Rakyat Aceh/PRA, Partai Suara Independen Rakyat Aceh/SIRA, Partai Aceh Aman Sejahtera/PAAS, Partai Bersatu Aceh/PBA, Partai daulat Aceh/PDA).

Keikut-sertaan tiga partai lokal itu pun tidak benar-benar partai baru. Partai Nasional Aceh merupakan perpecahan dari Partai Aceh. Sementara, Partai Damai Aceh merupakan perubahan nama dari Partai Daulat Aceh karena tak memenuhi ambang batas electoral threshold. Keikut-sertaan Partai Lokal dalam 
sejarah Pemilu Legislatif di Indonesia, Khususnya di Aceh memiliki landasan yuridis berlangsung pada pelaksanaan pemilihan umum legislatif pada tanggal 9 April 2009. Jika dilihat dari pelaksanaan Pemilu Legislatif tahun 2009 (sebanyak 36 Partai nasional), maka jumlah partai politik nasional (parnas) yang ikut pada pemilu legislatif 2014 mengalami penurunan yang signifikan yaitu sebanyak 12 partai nasional sebagai berikut Partai Nasional Demokrat (NASDEM), Partai Kebangkitan Bangsa (PKB), Partai Keadilan Sejahtera (PKS), Partai Demokrasi Indonesia Perjuangan (PDIP), Partai Golongan Karya (GOLKAR), Partai Gerakan Indonesia Raya (GERINDRA), Parta Demokrat (PD), Partai Amanat Nasional (PAN), Partai Persatuan Pembangunan (PPP), Partai Hati Nurani Rakyat (Hanura), Partai Bulan Bintang (PBB), Partai Keadilan dan Persatuan Indonesia (PKPI).

Agenda rutin pemilu legislatif 2014 merupakan bagian dari sistem demokrasi prosedural. Hal ini telah diamanahkan dalam UUD 1945 sebagai wujud pelaksanaan kedaulatan rakyat dalam sebuah negara yang melaksanakan sistem demokrasi. Khusus UU Pemilu untuk memilih anggota legislatif diatur dalam UU No. 12 Tahun 2003 yang telah diubah dengan UU No. 10 Tahun 2008. Adanya perbedaan peserta Pemilu Legislatif 2014 di Aceh yang melibatkan 3 partai lokal dan 12 partai nasional merupakan model perwujudan sistem demokrasi tersendiri bagi pemilih yang berada di Propinsi Aceh. Pilihan pemilih pada Pemilu Legislatif 2014 akan menentukan masa depan Aceh Baru.

Pada Pileg Aceh Tamiang Tahun 2019, sebanyak 20 Partai Politik Peserta Pemilu dengan komposisi 16 Partai Nasional dan 4 Partai Lokal yang juga ikut meramaikan kontestasi untuk memperebutkan 30 kursi DPRK Kabupaten Aceh Tamiang. Partai Gerindra terdapat 28 orang yang mendaftarkan diri menjadi calon anggota legislatif sebagai syarat sah untuk mengikuti kontestasi Pileg yang dibagi menjadi 3 daerah pemilihan (dapil) untuk mengikuti kontestasi Pileg.

Pemilihan Legislatif Kabupaten Aceh Tamiang pada Tahun 2019 yang berhasil lolos dan memperoleh kursi DPRK dari Partai Gerindra sebanyak 6 orang, 2 orang dari setiap dapil yakni: di dapil 1 ada Salbiah, S. Pd.I, dengan perolehan suara sebanyak 1.262 orang dan Muhammad Irwan, SP, dengan perolehan suara sebanyak 4.460, di dapil 2 dimenangkan oleh Suprianto, ST, dengan perolehan suara sebanyak 2.051 orang dan Sugiono Iskandar dengan perolehan suara sebanyak 2.436 orang. Sedangkan di dapil 3 dimenangkan oleh Sarhadi dengan perolehan suara sebanyak 2.887 orang dan Fitriadi dengan perolehan suara sebanyak 1.932 orang.

Dikarenakan Partai Gerindra memperoleh suara terbanyak dari Pemilihan Legislatif lantas menjadikan Partai Gerindra sebagai partai pemenang pada Pileg Tahun 2019 yang otomatis memperoleh kursi Ketua Dewan Pimpinan Rakyat Kabupaten Aceh Tamiang untuk periode 2019 - 2024 yang diberikan kepada Ketua Partai Gerindra Kabupaten Aceh Tamiang, yakni: Suprianto, ST oleh Pimpinan Partai Gerindra di tingkat Nasional.

\section{Faktor-Faktor Terpilihnya Anggota Legislatif Dari Partai Gerindra}

Modal politik menjadi sangat sentral bagi semua pasangan calon. Dapat dipastikan bahwa jika modal politik tidak baik maka hasilnya juga tidak baik. Dalam tulisan ini, faktor-faktor yang digolongkan sebagai modal politik adalah dukungan partai politik, kinerja tim sukses, dan kampanye (Liliana, 2015).

Pada Pemilihan Legislatif Kabupaten Aceh Tamiang tahun 2019, Partai Gerindra telah berhasil meloloskan 6 Calon Anggota Legislatif terpilih ini tidak terlepas dari dukungan partai politik. Mulai dari proses penjaringan, penetapan nomor urut, sampai ke dalam upaya memenangkan caleg tersebut. Apalagi partai politik menjadi satu-satunya syarat untuk dapat mencalonkan diri sebagai calon anggota legislatif agar dapat mengikuti kontestasi.

Dalam upaya memenangkan seluruh calon anggota legislatif peranan partai politik tidak dapat diabaikan karena masing-masing punya peranan tersendiri. Hal ini karena partaijuga ikut bekerja melalui jaringan struktur partai yang ada hingga ke desa-desa. Bahkan, saat melakukan proses di internal hingga ditetapkan menjadi calon oleh partai tersebut sangat mempengaruhi animo masyarakat. Bagi masyarakat, calon dari suatu partai politik sudah cukup layak sebagai calon yang ikut kontestasi Pileg.

Pada pileg tahun 2019 Partai Gerindra berhasil menyumbangkan suara partai 
sebanyak 2.551 suara sah atau setara dengan 1 kursi Dewan Pimpinan Rakyat Kabupaten Aceh Tamiang. Jumlah suara bisa dikatakan sangat signifikan, mengingat suara dari partai politik lain yang terbanyak tidak sampai setengahnya, yakni Partai Demokrat dengan perolehan suara partai sebanyak 1.225 suara sah.

Berbeda dengan partai politik yang kehadirannya sudah diperebutkan jauh sebelum pencalonan pasangan calon. Kehadiran tim sukses juga berpengaruh dalam menjelang diadakannya Pileg. Tim ini bisa berasal dari struktural ataupun luar partai politik pengusung atau kombinasi keduanya. Dalam menghadapi Pileg tahun 2019, pembentukan tim sukses yang berasal dari dalam dan luar partai politik. Tokoh masyarakat yang bukan kader partai "dirangkul" menjadi bagian dari tim suksesnya.

Tim sukses induk dari struktural partai dibentuk untuk bertanggung jawab di setiap Kecamatan yang dipimpin oleh Ketua Pimpinan Anak Cabang (PAC), selanjutnya membawahi tim sukses desa yang bekerja hingga wilayah Tempat Pemungutan Suara (TPS) dan mengkoordinir seluruh saksi yang berjaga di tiap-tiap TPS. Untuk tim sukses yang berasal dari luar Partai Gerindra dibentuk secara perseorangan oleh masing-masing caleg. Tim ini dibentuk berdasarkan tingkat loyalitas yang tinggi, dikenal, dan populer di kalangan masyarakat. Pemilihan tersebut ditargetkan menjadi lumbung suara seperti; tokoh agama, kelompok pertanian/perkebunan, perangkat desa, hingga sanak saudara yang dianggap memiliki kompetensi dalam menggalang suara, melakukan sosialisasi, dan kampanye ke masyarakat.

Sebelum berlangsungnya pemungutan suara, masing-masing caleg diberikan kesempatan melakukan kampanye yang dimaksudkan untuk bersosialisasi, mengutarakan program kerja serta menyerap aspirasi kepada calon pemilih. Kampanye dilakukan dengan slogan, pembicaraan/dialog, barang cetakan, penyiaran barang rekaman berbentuk gambar atau suara, dan simbolsimbol. Program kerja tersebut sebagai bekal bagi calon pemilih dalam menenentukan pilihannya nanti pada saat pencoblosan (Husna, 2017).

Pada kenyataannya, pemilih yang mencoblos dan mendukung tidak terlalu mendengarkan materi kampanye saat disosialisasikan. Pengalaman para pemilih, banyak dari caleg-caleg yang sudah terpilih tetapi tidak menepati janji-janji saat masa kampanye hingga tidak pernah lagi berkunjung ke daerah-daerah yang dulunya pernah dikunjungi saat masa kampanye berlangsung. karena itu masyarakat lebih cenderung mencari tahu rekam jejak dan bagaimana keseharian caleg tersebut sebelum maju dalam kontestasi Pileg .

Modal sosial adalah bagian dari apa yang harus dimiliki oleh seorang calon pemimpin. Melalui modal sosial yang dimiliki, para pemilih bisa melakukan penilaian apakah pasangan yang ada itu benar-benar layak untuk dipilih atau tidak. Dalam tulisan ini, faktor-faktor yang digolongkan sebagai modal sosial adalah rekam jejak, peranan tokoh agama dan tokoh masyarakat, dukungan media massa/pers, dan primordial.

Suprianto, ST memiliki modal sosial yang relatif baik di daerah pemilihannya dan lumayan dikenal di Kabupaten Aceh Tamiang dikarenakan beliau sudah berkecimpung di dunia politik melalui Partai Gerindra mulai dari Tahun 2013 sebagai kader dan dilantik sebagai Ketua DPC Partai Gerindra pada tahun 2016, Suprianto sudah cukup dikenal di daerah pemilihannya sebagai Pengusaha di Kota Medan yang sering berkontribusi untuk pembangunan Desa dengan menggunakan dana pribadi, seperti rutin setiap tahunnya menyumbangkan hewan untuk dikurban pada Hari Raya Idul Adha, santunan anak yatim, memberi sarung dan jelbab untuk pengajianpengajian yang sering dihadiri dan pimpinan pengajian dan para ustadznya akrab dengan beliau serta pelatihan membuat kue untuk ibuibu agar bisa lebih produktif, dan itu semua dilakukan jauh-jauh hari sebelum masa penetapan bakal calon anggota legislatif.

Suprianto juga dicitrakan oleh masyarakat sebagai pribadi yang rendah hati, tidak berjarak dengan masyarakat, selalu menghadiri setiap undangan yang diberikan oleh masyarakat, dan lebih sering menjadi pendengar dari pada berbicara saat berkumpul dengan masyarakat dan Suprianto juga dikenal sebagai sosok pengayom yang mampu menempatkan dirinya sebagai pemimpin bagi semua kalangan tanpa membedakan agama dan suku. Meski di daerah pemilihannya mayoritas bersuku Aceh dan Suprianto sendiri bersuku jawa tidak menjadi halangan baginya 
dalam memilih tim sukses dan merangkul konstituen, banyak pemilih dan tim suksesnya bersuku Aceh. Hal ini membuat stabilitas dan keharmonisan yang senantiasa kondusif di dapil tersebut.

Kepopulerannya tidak terlepas karena orang tuanya merupakan imam Masjid di kampung tersebut dan transmigran yang sudah cukup lama menduduki daerah Aceh Tamiang bahkan sebelum pemekaran pada tahun 2002. Dalam upaya pemenangan Suprianto peranan tokoh agama dan tokoh masyarakat cukup signifikan karena dilibatkan dalam melakukan sosialisasi terhadap program kerja, citra pribadi, dan rekam jejak suprianto. Ada beberapa tokoh agama yang dilibatkan secara langsung ke dalam tim sukses dan ada pula yang tidak terdaftar sebagai tim sukses dikarenakan beberapa tokoh agama hanya ingin terlibat dalam memberikan doa saja tetapi tidak ingin terlibat langsung dalam politik praktis, namun tidak semua anjuran tokoh masyarakat maupun tokoh agama yang serta merta dituruti oleh calon pemilih. Sebab kadang-kadang mereka diperhadapkan kepada situasi yang membuat mereka sendiri menjadi bingung dalam menentukan pilihannya. Ada juga tokoh agama atau tokoh masyarakat yang "memberikan" dukungannya kepada lebih dari satu pasangan calon dengan cara mendoakan atau mengkampanyekannya, hal ini sudah pasti membingungkan para jemaat atau masyarakat yang notabene adalah calon pemilih.

Media massa dan pers merupakan "rekan" yang sangat banyak membantu, baik dalam memberikan masukan, memberikan kritikan, dan memberitakan aktifitas kampanye yang dilakukan, maupun memberitakan program-programnya saat kampanye. Tetapi dalam konteks Pileg, peran pers tidak signifikan dalam memberitakan program-program, mayoritas masyarakat masih kurang meminati berita dan tidak sempat mencari informasiinformasi yang disajikan, karena kegiatan masyarakat sebagai petani dan nelayan sudah sangat menyita waktu keseharian mereka. Walaupun Suprianto lebih memprioritaskan kunjungan dan dialog tatap muka tetapi beliau memaksimalkan peran pers untuk kampanyenya melalui media online seperti Facebook dan portal berita dari media lokal yang juga diminati oleh masyarakat.

Banyak pihak mengatakan bahwa faktor suku mempengaruhi dalam menentukan keterpilihan seseorang dalam pemilu, karena suku dapat diartikan kekerabatan dan persekutuan dari orang-orang yang dianggap bergaris keturunan sama, kesamaan budaya, bahasa, dan agama.

Dalam konteks pileg tahun 2019 khususnya di dapil Suprianto, faktor primordial tidak terlalu dominan lagi seperti pileg periode sebelum-sebelumnya. Informan dari kategori pemilih semuanya bersuku Aceh dan mengutarakan bahwa di periode sebelumnya mereka selalu memilih caleg yang berasal dari Partai Aceh yang notabene seluruhnya adalah suku Aceh dan didominasi oleh mantan kombatan Gerakan Aceh Merdeka (GAM).

Para pemilih berpaling ke caleg Partai Gerindra dikarenakan faktor primordial tidak menentukan komitmen-komitmen caleg saat masa kampanye akan dituntaskan jika sudah terpilih, banyak dari caleg yang mereka pilih berdasarkan suku yang sama tetapi tidak merealisasikan program kerja dan kontrakkontrak politik yang dibuat saat masa kampanye, bahkan ada beberapa caleg yang tidak pernah menyambangi kembali daerahdaerah yang pernah dikunjunginya dan menjadi basis suaranya saat masa kampanye. Pada akhirnya pemilih lebih tertarik kepada rekam jejak dan citra kandidat para caleg yang menurut para pemilih faktor tersebut lebih meyakinkan terhadap bagaimana seorang caleg jika sudah terpilih dari pada hanya memilih berdasarkan suku.

Semua caleg membutuhkan sejumlah dana/uang untuk mengikuti kompetisi dalam Pileg. Pemilu secara langsung jelas membutuhkan biaya yang besar. Modal yang besar tidak hanya dipakai untuk membiayai kampanye, tetapi juga untuk membangun relasi dengan para calon pendukungnya, termasuk di dalamnya adalah modal untuk memobilisasi dukungan pada saat menjelang dan berlangsungnya masa kampanye (Anderson, 1992).

Tidak dapat dipungkiri bahwa caleg dari Partai Gerindra Aceh Tamiang juga membutuhkan dana yang cukup besar untuk upaya memenangkan Pileg. Bahkan dalam penjaringan bakal calon anggota legislatif yang dilakukan oleh DPC Partai Gerindra Aceh Tamiang menjadikan kemampuan dana menjadi syarat mutlak, di samping kapasitas dan rekam jejak para bakal calon agar dapat menjadi caleg. Seperti yang diutarakan oleh 
informan dari kategori anggota legislatif terpilih yakni Fitriadi yang berasal dari dapil 3, sekurang-kurangnya menghabiskan dana Rp. 500.000.000,- (lima ratus juta rupiah). Mulai masa kampanye hingga selesai dan berbeda sedikit nominalnya dengan Ketua DPRK terpilih yakni Suprianto, sebanyak Rp. 800.000.000,-.

Dana yang besar mereka perlukan mulai dari proses penentuan menjadi calon dari internal partai, kampanye, menghadapi sengketa, hingga pelantikan. Dana tersebut digunakan untuk beragam kepentingan, antara lain untuk biaya mencetak alat peraga, biaya transportasi tim sukses, biaya memobilisasi massa saat kampanye, biaya konsumsi tim sukses dan massa calon pendukung, dan berbagai keperluan lainnya. Menurut Suprianto, dana politik proses awal hingga berakhir masa kampanye sangat besar. Tetapi meski besar, hal ini wajib dilaksanakan karena sekaligus merupakan sosialisasi dalam rangka memperkenalkan diri sebagai seorang bakal calon. Sebab tidak mungkin seseorang bersedia datang nantinya saat kampanye kalau belum kenal dengan calon yang berkampanye, apalagi mendukungnya. Proses penentuan calon dari partai ini juga merupakan tahapan dalam pembentukan tim kampanye atau tim sukses.

Namun juga ada beberapa hal yang sangat disayangkan ada beberapa masyarakat yang sudah terbiasa diberikan hadiah oleh calegcaleg, jadi masyarakat terbiasa menjadi pragmatis dan terkesan menjual suara dari pada memilih karena rekam jejak dan citra kandidat, tentu hal ini harus dihilangkan dengan dimulai dengan mereduksi hal-hal negatif tersebut yang mengarah ke money politic (Linz \& Stepan, 2001).

\section{SIMPULAN}

Peranan partai politik sangat dominan, karena partai juga ikut bekerja untuk memenangkan mereka melalui jaringan struktur partai yang ada hingga ke desa-desa. Caleg dari Partai Gerindra membentuk tim sukses yang mampu dan efektif melakukan pendekatan kepada masyarakat untuk meraih dukungan dan memilih pasangan tersebut. Rekam jejak merupakan faktor yang sangat memengaruhi keterpilihan anggota legislatif tersebut. Dalam upaya pemenangan, peranan tokoh agama dan masyarakat cukup signifikan karena dilibatkan dalam melakukan sosialisasi terhadap program kerja, citra pribadi, dan rekam jejak. Dalam Pileg, peran pers tidak terlalu signifikan dalam memberitakan program-program. Mayoritas masyarakat kurang meminati berita yang disajikan oleh media. Dana kampanye menjadi salah satu faktor terpenting yang sangat mempengaruhi terpilihnya anggota legislatif. Bahkan dalam penjaringan bakal calon anggota legislatif, DPC Partai Gerindra Aceh Tamiang menjadikan kemampuan dana menjadi syarat mutlak di samping kapasitas dan rekam jejak para bakal calon agar dapat menjadi caleg dari Partai Gerindra.

\section{DAFTAR PUSTAKA}

Azlansyah, S., Astuti, R., \& Priyadi, B. (2020). Divided Government and Its Impact on the Performance of Legislation in the Indonesian Province of Aceh. JPPUMA: Jurnal Ilmu Pemerintahan dan Sosial Politik UMA (Journal of Governance and Political Social UMA), 8(1), 28-36. doi:https://doi.org/10.31289/jppuma.v8i1.3 073

Anderson, B. (1992). Imagined Communities: Komunitas-Komunitas Terbayang. Insist.

Basri, H. (2014). Using Qualitative Research in Accounting and ManagementStudies: Not a New Agenda. Journal of US-China Public Administration, 11(10), 831-838. https://doi.org/10.17265/1548-6591

Budiarjo, M. (2008). Dasar-dasar Ilmu Politik: Edisi Revisi. PT Gramedia Pustaka Utama.

Fatkhurohman. (2010). Pilkada dan Masa Depan Penguatan Demokrasi di Daerah. Jurnal Konstitusi, 3(2), 29-49.

Fauzi. (2018). Komunikasi Politik Calon Legislatif dalam Memengaruhi Partisipasi PolitikMasyarakat di Kabupaten Aceh Utara. Jurnal Pekommas, 3(1), 63-78.

Husna, A. (2017). Analisis Political Branding Calon Kepala Daerah Dalam Pilkada Aceh 2017. Jurnal Komunikasi Global, 6(1), 56-73. http://jurnal.unsyiah.ac.id/JKG/article/view $/ 9190$

Iver, R. M. Mac. (1984). Negara Modern = The Modern State. Aksara Baru.

Kadir, A., (2013). Peranan Partai Politik dalam Menanggulangi Golongan Putih (Golput) pada Pemilihan Legislatif 2009, JPPUMA: Jurnal Ilmu Pemerintahan dan Sosial Politik UMA (Journal of Governance and Political UMA), 1 (1): 65-75.

Liliana, N. R. (2015). Strategi Komunikasi Pemasaran Politik Dalam Kampanye Calon Legislatif (Caleg) Terpilih Partai Persatuan Pembangunan (PPP) Dalam Pemenangan 
Pileg 2014 Kota Pekanbaru. Jom FISIP, 2(2), $1-11$.

Linz, J. J., \& Stepan, A. (2001). Menjauhi Demokrasi Kaum Penjahat: Belajar Dari Kekeliruan Negara-Negara Lain. LIPI ; Ford Foundation.

Manurung. E.M (2019). Kecenderungan Perilaku Narsistik Pada Calon Legislatif. Journal of Education, Humaniora and Social Sciences (JEHSS). 1 (3): 196-201.

Sari, D., Darmawan, W., \& Manan, F. (2021). Rekrutmen Calon Legislatif Muda Partai Golongan Karya Untuk Dewan Perwakilan Rakyat Republik Indonesia Periode 20192024. Journal of Education, Humaniora and
Social Sciences (JEHSS), 3(3), 987-995. doi:https://doi.org/10.34007/jehss.v3i3.468

Pangestu, A., Agustino, L., \& Bintari, A. (2021). Faktor-faktor yang Mempengaruhi Partisipasi Politik Penyandang Disabilitas Sebagai Calon Anggota Legislatif Pada Pemilu Tahun 2019. Journal of Education, Humaniora and Social Sciences (JEHSS), 3(3), 1193-1201.

doi:https://doi.org/10.34007/jehss.v3i3.520 Undang-Undang Republik Indonesia Nomor 2 Tahun 2011 Tentang Partai Politik.

Undang-Undang Republik Indonesia Nomor 7 Tahun 2017 Tentang Pemilihan Umum. 